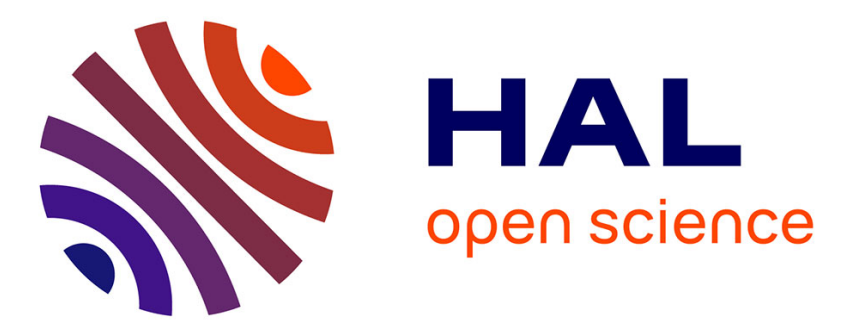

\title{
Variations in the accumulation, localization and rate of metabolization of selenium in mature Zea mays 2 plants supplied with selenite or selenate
}

Melanie Longchamp, Maryse Castrec-Rouelle, Philippe Biron, Thierry Bariac

\section{- To cite this version:}

Melanie Longchamp, Maryse Castrec-Rouelle, Philippe Biron, Thierry Bariac. Variations in the accumulation, localization and rate of metabolization of selenium in mature Zea mays 2 plants supplied with selenite or selenate. Food Chemistry, 2015, 182, pp.128-135. 10.1016/j.foodchem.2015.02.137 . hal-01132891

\section{HAL Id: hal-01132891 \\ https: / hal.sorbonne-universite.fr/hal-01132891}

Submitted on 18 Mar 2015

HAL is a multi-disciplinary open access archive for the deposit and dissemination of scientific research documents, whether they are published or not. The documents may come from teaching and research institutions in France or abroad, or from public or private research centers.
L'archive ouverte pluridisciplinaire HAL, est destinée au dépôt et à la diffusion de documents scientifiques de niveau recherche, publiés ou non, émanant des établissements d'enseignement et de recherche français ou étrangers, des laboratoires publics ou privés. 


\section{Variations in the accumulation, localization and rate}

2 of metabolization of selenium in mature Zea mays

4

\section{plants supplied with selenite or selenate}

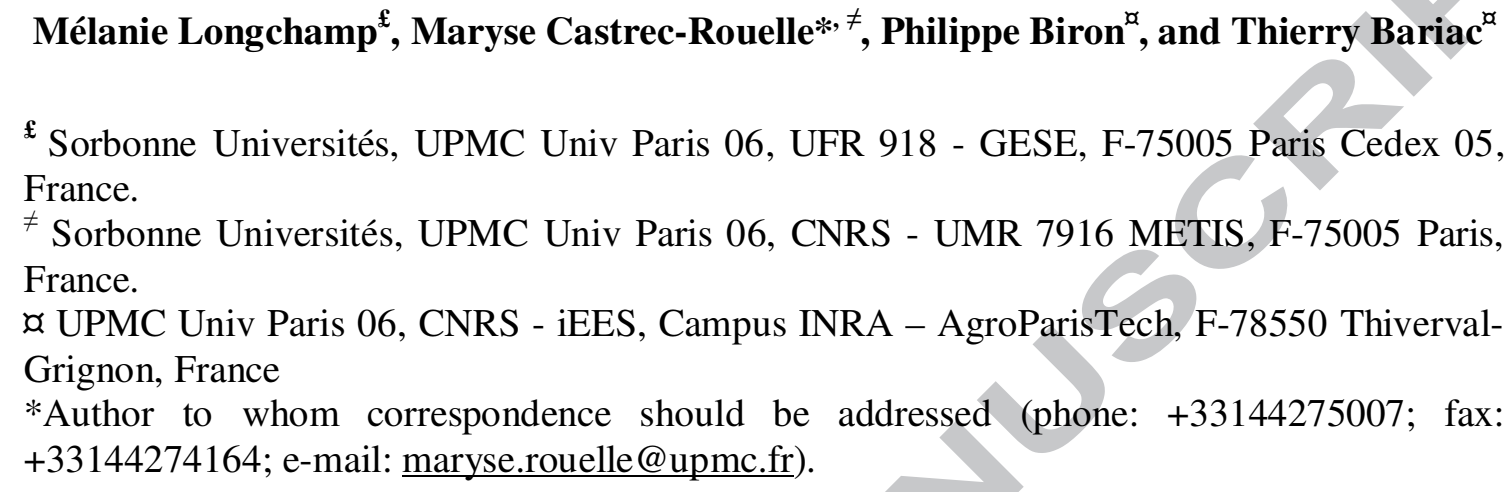
France.

* Sorbonne Universités, UPMC Univ Paris 06, CNRS - UMR 7916 METIS, F-75005 Paris, France.

a UPMC Univ Paris 06, CNRS - iEES, Campus INRA - AgroParisTech, F-78550 ThivervalGrignon, France

*Author to whom correspondence should be addressed (phone: +33144275007; fax: +33144274164; e-mail: maryse.rouelle@upmc.fr).

\section{Highlights}

- Selenate decrease grain biomass whereas selenite decrease number of grains per plant

- Selenite treatment results in higher selenium accumulation in grains than selenate treatment

- For both selenite and selenate treatments, selenium in grains is exclusively organic selenium compounds

- For humans, selenite treatment increases bioavailable selenium in grains

- Selenate is the best supplement to enrich Zea mays forage for bioavailable selenium 


\section{Abstract}

26 Quantification of selenium bioavailability from foods is a key challenge following the 27 discovery of the antioxidant role of this micronutrient in human health. This study presents 28 the uptake, accumulation and rate of metabolization in mature Zea mays plants grown in 29 hydroponic solution supplemented with selenate or selenite.

30 Selenium content was lower in plants supplemented with selenate and accumulated mainly in 31 the leaves compared with selenite-treated plants where the selenium was retained in the roots.

32 Selenite-treated grains accumulated more selenium. Selenate was metabolized less than 33 selenite in whole plants, but in grains selenium was present exclusively as organic selenium 34 compounds.

35 For humans, the bioavailability of organic selenium was evaluated at $90 \%$ compared with 36 only $50 \%$ for inorganic forms. Our results show that the potential for selenium bioavailability 37 is increased with selenite treatment. Keywords: Selenite, selenate, selenium bioavailability, enzymatic extraction, organoselenium compounds, biofortification 


\section{INTRODUCTION}

Selenium (Se) is an essential micronutrient in human and animal diets. More than 20 selenoproteins or selenoenzymes are involved in normal metabolism and selenium has also been proposed to lower the risk of cardiovascular diseases and cancer (Rayman, 2008; Thomson, 2004). Food is the principal route of selenium intake. Meat and seafood contain the highest amounts of selenium, with 0.4-1.5 $\mu \mathrm{g}$ per gram (Rayman, 2008), but cereals, fruits and vegetables are also good food sources. Selenium enters the food chain through plants and especially crops, which are part of the diet of both primary and secondary consumers.

Selenium concentrations in food, including crops, depend not only on selenium concentrations in agricultural soils (which vary considerably between countries and regions) but also on selenium phytoaccessibility controlled by many abiotic and biotic factors such as soil $\mathrm{pH}$, redox conditions, organic matter content, microbial activities, irrigation and compaction. In some countries or regions, low selenium levels in soil lead to low concentrations in feed or forage, which in turn can result in selenium deficiency in livestock and humans. For example, the average selenium intake is only $36 \mu \mathrm{g}$ per day in France, $34 \mu \mathrm{g}$ per day in the UK and $35 \mu \mathrm{g}$ per day in Sweden (Rayman, 2008); these levels are below the recommended dietary allowance of 40 to $70 \mu \mathrm{g}$ per day (World Health Organization et al., 1996). To increase selenium levels in human and animal diets, several processes have been developed including mineral supplementation, genetic biofortification (plant breeding) and finally, the option chosen here, agronomic biofortification of food or forage.

In contrast to humans, the role of selenium for plants is more ambiguous, although studies on young plants have led to a better understanding of selenium pathways in higher plants (De Souza et al., 1998; Hopper \& Parker, 1999; Li, McGrath \& Zhao, 2008; Terry, Zayed, De Souza \& Tarun, 2000; Ximenez-Embun, Alonso, Madrid-Albarran \& Camara, 2004; Zayed, Lytle \& Terry, 1998; Zhang, Pan, Chen \& Hu, 2003). Plant development and selenium 
67 metabolism are strongly dependent on the form of supplied selenium. The greater mobility of

68 selenate compared to selenite results in differences in the absorption, translocation and 69 metabolism of selenium within the plant. Indeed, when plants are exposed to selenite, 70 selenium accumulation is less than after selenate treatment (De Souza et al., 1998; Terry et al,, 71 2000; Ximenez-Embun et al., 2004; Zhang et al., 2003), with a greater reduction in biomass 72 production (Hopper et al., 1999; Ximenez-Embun et al., 2004). After selenate treatment, 73 selenium is almost entirely translocated to the leaves and weakly metabolized as selenoamino74 acids, with a selenate concentration in shoots (i.e. stems and leaves) representing more than $7590 \%$ of the total shoot selenium (De Souza et al., 1998; Hopper et al., 1999; Li et al., 2008; 76 Mazej, Osvald \& Stibilj, 2008; Terry et al., 2000; Ximenez-Embun et al., 2004; Zayed et al., 77 1998; Zhang et al., 2003). In contrast, when supplied as selenite, selenium accumulates 78 principally in roots with little translocation, although selenoamino-acid production 79 (principally selenomethionine, selenocysteine and selenomethylselenocysteine) is greater (De 80 Souza et al., 1998; Hopper et al., 1999; Li et al., 2008; Liu \& Gu, 2009; Terry et al., 2000; 81 Ximenez-Embun et al., 2004; Zayed et al., 1998) and the selenium volatilization rate is about 82 2-fold higher from those plants (De Souza et al., 1998).

83 After ingestion by humans or animals, bioavailable selenium is the fraction that enters the 84 systemic circulation (Thiry, Ruttens, De Temmerman, Schneider \& Pussemier, 2012). As with 85 other micronutrients, selenium bioavailability strongly depends on the chemical form of the 86 element: organic forms (such as Se-methionine and Se-cysteine), mainly from plant and 87 animal sources, have more bioavailability than inorganic forms (selenate and selenite), which 88 are principally found in dietary mineral supplements. Experimental designs used to measure 89 selenium bioavailability vary widely in the literature, making it difficult to compare the 90 results (Knowles, Grace, Wurms \& Lee, 1999; Nicholson, McQueen \& Bush, 1991; Podoll, 91 Bernard, Ullrey, Debar, Ku \& Magee, 1992). According to Thomson (2004), the apparent 
absorbed selenium (i.e. the difference between selenium ingested and selenium excreted in feces and urine) in humans was evaluated at about $90 \%$ for Se-met and Se-cys versus $50 \%$ for selenite or selenate supplements (Panel on Dietary Antioxidants and Related Compounds, Subcommittee on Upper Reference Levels of Nutrient, Subcommittee on Interpretation and Uses of DRIs, Standing Committee in the Evaluation of Dietary Reference Intakes of the Food and Nutrition Board, Institute of Medecine \& the National Academies and Health Canada, 2000). However, due to a lack of data on the bioavailable fraction across all food products, the recommended daily dietary allowances of selenium for humans are based only on the total selenium concentration, without taking into account the speciation. The two percentages (90\% and 50\%) estimated by Thomson (2004) are a "pseudo reference" value used in the present study to evaluate the selenium bioavailability in our so-called "organic" and "inorganic" fractions in Zea mays plants.

Due to the essential function of selenium in staple foods, a number of recent studies on grains and seeds have been carried out not only in wheat, but also in sesame, buckwheat pumpkin and Zea mays (Broadley et al., 2010; Cubadda et al., 2010; Kapolna, Gergely, Dernovics, Illès \& Fodor, 2007; Mbagwu, 1983; Moore et al., 2010; Smrkolj, Osvald, Osvald \& Stibilj, 2007; Smrkolj, Stibilj, Kreft \& Kapolina, 2005; Stibilj, Kreft \& Smrkolj, 2004). In Brassica rapa (Lyons, Genc, Soole, Stangoulis, Liu \& Graham, 2009), selenite fertilization increased seed number and weight produced by each plant. Regardless of the enrichment procedures employed in agricultural practice, the development and growth of plants and grains were not affected negatively by selenium supplementation (Broadley et al., 2010; Stibilj et al., 2004). Independently of the selenium concentration added as amendment, grains seem to be an ideal storage tissue, with selenium concentrations higher than in shoots or fruits (Cubadda et al., 2010; Mbagwu, 1983; Stibilj et al., 2004). It has previously been shown that the major selenium species in grains is selenomethionine accounting for $45 \%$ to $90 \%$ of total 
117 selenium (Cubadda et al., 2010; Kapolna et al., 2007; Smrkolj et al., 2007; Smrkolj et al.,

118 2005), with only very low levels of selenate detected (Cubadda et al., 2010; Lyons, Genc,

119 Stangoulis, Palmer \& Graham, 2005).

120 In the present study, we investigated selenium enrichment in Zea mays grains grown in a 121 hydroponic system. Cereal grains are rich in phytic acids, known for their antioxidant roles in

122 humans and which strongly bind mineral and trace elements (Hurrel, 2003). Zea mays grains

123 contain more of this compound than wheat grains (Egli, Davidsson, Juillerat, Bearclay \&

124 Hurrell, 2003). Moreover, Zea mays is the most widely cultivated cereal in the world,

125 producing mainly forage and grains for animal feed but also grains as well as derived products

126 for human consumption. In Malawi, for instance, $50 \%$ of the diet is derived from Zea mays

127 (Chilimba et al., 2011). Consequently, the limited data available on selenium accumulation in

128 Zea mays grains has been obtained in specific locations (selenium-deficient (Chilimba et al.,

129 2011) or seleniferous areas) or for Se-supplemention, fly-ash for example (Mbagwu, 1983).

130 Furthermore, the influence of the chemical form of selenium in Zea mays plants, on

131 accumulation including location (i.e. roots, stems, shoots and grains), has not been widely

132 studied. The first objective of the present study was, therefore, to quantify the effects of those

133 two inorganic chemical forms (selenate and selenite) on Zea mays growth and seed

134 production. The second aim was to investigate the uptake, translocation and speciation of

135 selenium in different Zea mays tissues: roots, stems, leaves and grains.

136 
137

138

139

140

141

142

143

144

145

146

147

148

149

150

151

152

153

154

155

156

157

159

160

161

158 The change in aerial biomass production was followed by recording the leaf area five times

\section{MATERIALS AND METHODS}

\subsection{Seed germination and culture conditions}

Three weeks after germination, Zea mays sups.mays (L.) corn seedlings were cultivated in hydroponic conditions in $20 \mathrm{~L}$ plastic tanks filled with a modified Hoagland nutrient solution consisting of $\mathrm{KNO}_{3}\left(3 \mathrm{mmol} . \mathrm{l}^{-1}\right), \mathrm{Ca}\left(\mathrm{NO}_{3}\right)_{2} .4 \mathrm{H}_{2} \mathrm{O}\left(2.72 \mathrm{mmol.} \mathrm{l}^{-1}\right), \mathrm{NH}_{4} \mathrm{NO}_{3}\left(2 \mathrm{mmol.} \mathrm{l}^{-1}\right), \mathrm{NaCl}$ $\left(0.2\right.$ mmol. $\left.{ }^{-1}\right), \mathrm{KH}_{2} \mathrm{PO}_{4}\left(0.98 \mathrm{mmol}^{-1}\right), \mathrm{MgSO}_{4} .7 \mathrm{H}_{2} \mathrm{O}\left(0.70 \mathrm{mmol.} \mathrm{l}^{-1}\right),\left(\mathrm{NH}_{4}\right)_{6} \mathrm{Mo}_{7} \mathrm{O}_{24 .} 4 \mathrm{H}_{2} \mathrm{O}$ (0.04 $\mu$ mol. $\left.1^{-1}\right), \mathrm{H}_{3} \mathrm{BO}_{3}\left(24 \mu \mathrm{mol} .1^{-1}\right), \mathrm{MnSO}_{4}\left(13 \mu \mathrm{mol} . \mathrm{I}^{-1} \mathrm{M}\right), \mathrm{ZnSO}_{4}\left(6 \mu \mathrm{mol} . \mathrm{I}^{-1}\right), \mathrm{CuSO}_{4}(1.5$ $\mu$ mol. $\left.1^{-1}\right)$ and FeEDDHA (6\%) $\left(4 \mu \mathrm{mol}^{-1} \mathrm{l}^{-1}\right)$. Two nutrient solutions were supplemented with $12 \mu$ mol. $1^{-1}$ selenium as either $\mathrm{Na}_{2} \mathrm{SeO}_{4}$ or $\mathrm{Na}_{2} \mathrm{SeO}_{3}$ (solutions $\mathrm{Se}^{\mathrm{VI}}-\mathrm{T}$ and $\mathrm{Se}^{\mathrm{IV}}-\mathrm{T}$ ), respectively. Under control conditions (C-T), no selenium was added. Five corn seedlings were transplanted in each tank and placed into a RUBIC5 plant growth chamber (Reactor Used for Continental Isotopic Biogeochemistry), a $9 \mathrm{~m}^{3}$ sealed chamber (Servathin, France) the atmospheric compositions of which are controlled. Lighting was provided by $15 \times 400$ watt Philips Son-T Agro bulbs over an 8-hour photoperiod set at $600 \mu \mathrm{M} \cdot \mathrm{m}^{-2} \cdot \mathrm{s}^{-1}$ photosynthetically active radiation at plant height. Air temperature was set at $25^{\circ} \mathrm{C}$ during the day and $18^{\circ} \mathrm{C}$ at night. Air humidity was controlled by a dew point condenser in order to maintain a set-point of $70 \%$ relative humidity. Beyond this set point, excess water vapor was condensed and collected using an Isco 3700 water sampler (so called "condensates"). The $\mathrm{CO}_{2}$ concentration was measured using a LI-COR (Lincoln, Nebraska USA) Li620 infrared gas analyzer set at 400 ppmv. The chamber had a slight positive pressure of $+20 \mathrm{~Pa}$ to avoid entry of outside air. Data were logged by a computer and averaged at 10 min intervals. during the experiments.

At maturity, plants (five for each treatment) were harvested and roots briefly rinsed in deionized water to remove traces of nutrient solution. The selenium concentration in this rinse 
162 water fell below the detection threshold of CRC-ICP-MS. The leaves, stems, roots and grains

163 were then separated. Plant samples were freeze-dried, ground with an automatic agate mortar, 164 and dry weights (DW) were measured.

165

\subsection{Total selenium analysis}

167 A suitable amount of powdered plant tissue (about $100 \mathrm{mg} \mathrm{DW}$ ) was digested in $2 \mathrm{ml}$ of $168 \mathrm{HNO}_{3}(70 \%)$ at $100^{\circ} \mathrm{C}$ for 24 hours in a closed digestion vessel. After cooling, $1 \mathrm{ml} \mathrm{of} \mathrm{H}_{2} \mathrm{O}_{2}$ $169(30 \%)$ was added and the sample was heated again at $100^{\circ} \mathrm{C}$ for 24 hours. The selenium 170 concentration in the digested tissues samples was determined by inductively coupled plasma 171 atomic emission spectrometry (ICP-AES, JY 2000, LOD: $50 \mu \mathrm{g} . \mathrm{l}^{-1}$ ). A blank and a reference 172 material (White clover, BCR402- IRMM) were included in each batch of samples. In the C-T 173 plants, the selenium concentrations fell below the detection threshold of ICP-AES.

174 Condensate selenium concentrations were determined by graphite furnace atomic absorption

175 spectrometry (GFAAS, UNICAM 989 QZ, LOD: $1.5 \mu \mathrm{g} \cdot 1^{-1}$ ). A certified reference material 176 (TMDA-64- Environment Canada) and a blank were included in each batch of samples.

\subsection{Separation and quantification analysis of selenate and selenite}

179 For enzyme hydrolysis, a DW sample of about $100 \mathrm{mg}$ was digested with $20 \mathrm{mg}$ of

180 Streptomyces protease (Protease Type XIV $\geq 3.5$ units $/ \mathrm{mg}$ solid from Streptomyces griseus,

181 Sigma Aldrich, Saint-Quentin Fallavier, France), dissolved in $5 \mathrm{ml}$ of $30 \mathrm{mmol} / \mathrm{I}^{-1}$ Tris- $\mathrm{HCl}$

182 buffer ( $\mathrm{pH}=7$, Rockland) and heated at $37^{\circ} \mathrm{C}$ for 24 hours under regular agitation (DigiPREP

183 Jr). Samples were then centrifuged at $4000 \mathrm{rpm}$ for $30 \mathrm{~min}$ (Eppendorf 5810 centrifuge). The 184 supernatants were filtered and stored at $4^{\circ} \mathrm{C}$ in $0.1 \%$ mercaptoethanol ( $\beta$-mercaptoethanol 185 molecular biology grade $99.8 \%$, Calbiochem) to avoid oxidation. To determine the efficiency 186 of enzymatic extraction, total selenium concentrations for each sample were determined by 
187 ICP-AES (LOD: $10 \mu \mathrm{g} .1^{-1}$ ). To identify selenate and selenite fractions, the two inorganic forms

188 were separated by HPLC (Dionex, ICS 3000) using a high pressure pump and an anion

189 exchange column (AS15, 4x250 mm) under the following conditions:

$190 \quad$ - mobile phase: $30 \mathrm{mmol.} \mathrm{I}^{-1} \mathrm{KOH}$

191 - flow rate: isocratic at $1 \mathrm{ml} / \mathrm{min}$

192 - injected sample volume: $200 \mu 1$

193 - column temperature: $30^{\circ} \mathrm{C}$

194 Standard solutions of the selenium species - Se(IV) (Sodium selenite 99\%, Sigma Aldrich,

195 Saint-Quentin Fallavier, France) and Se(VI) (Sodium selenate anhydrous, Sigma Aldrich) -

196 were prepared at suitable concentrations. The chromatography system was off-line to GFAAS

197 (LOD: $1.5 \mu \mathrm{g} . \mathrm{l}^{-1}$ ) used for detection and quantification. The detection limits for each

198 inorganic species were $5 \mu \mathrm{g} . \mathrm{g}^{-1}$ (i.e. $5 \%$ of total selenium) in plant tissues.

199

\subsection{Calculation of leaf area}

201 Measuring leaf area is a non-destructive method of monitoring plant growth during

202 experimental studies. Leaf area was calculated using the following formula (Fakorede,

203 Mulamba \& Mock, 1977; Ruget, Bonhomme \& Chartier, 1996):

204

205

206

207

208

209

210

$$
\text { Leaf area }=\sum_{i=1}^{n}(L i * l i * 0.75)
$$

( $L$ in $m$ : length of leaf; $l$ in m: width of leaf; $n$ : leaf number per plant)

\subsection{Statistical analysis}

In our study, the number of samples was less than 30 (i.e. five plants). Non-parametric tests were used for the statistical analysis. The significance of the effect of treatment conditions was determined with a bilateral Mann-Whitney test (to compare 2 groups) or 
211 Kruskal-Wallis test (to compare more than 2 groups), with an alpha risk equal to 0.05 . These

212 tests calculated the probability $\mathrm{P}$ of the difference between groups being random. $\mathrm{P}$ values less

213 than $5 \%$ were considered statistically different. In the figures, the results of statistical tests are

214 represented by the letters a, b and c. In this study, values are presented with the median (Q1; 215 Q3). 
216

217

218

219

220

221

222

223

224

225

226

227

228

229

230

231

232

233

234

235

236

237

238

239

240

\section{RESULTS}

\subsection{Biomass production}

Plant growth was monitored throughout the experiment by measuring leaf area, internode size and dry weights after harvest and drying.

Before day 20 and after day 75, there was no significant difference in the leaf areas between the three treatments (Figure 1.A). However, between days 30 and 70, the leaf area of $\mathrm{Se}^{\mathrm{IV}}$-T plants was on average $42 \%$ smaller than for control plants. At the end of experiment, the internode size of each plant was measured (Figure 1.B). For $\mathrm{Se}^{\mathrm{IV}}-\mathrm{T}$, the internodes No. 3 to No. 9 were on average $2.3(1.7 ; 2.5)$ times shorter than those of control plants. The largest difference was measured for the seventh internode, which was 2.9 times smaller in $\mathrm{Se}^{\mathrm{IV}}-\mathrm{T}$ plants versus controls.

Moreover, again for $\mathrm{Se}^{\mathrm{IV}}-\mathrm{T}$, the biomass production of plants (Figure 2.A) as well as the biomass production of shoots (data not shown) was about $70 \%$ less than C-T plants.

For grains, dry weights decreased by $60 \%$ and $80 \%$ in $\mathrm{Se}^{\mathrm{VI}}-\mathrm{T}$ and $\mathrm{Se}^{\mathrm{IV}}-\mathrm{T}$ plants, respectively, compared to the control plants (Figure 2.B). The grain number produced by each plant (Figure 2.C) decreased significantly (70\%) with selenite. Biomass allocation was affected by selenium; the ratio of grain dry weights to shoot dry weights was less with both selenium treatments compared with C-T. In fact, grain biomass for the C-T plants represented $33 \%$ of aerial biomass, but fell to $21 \%$ when selenium was present in the nutrient solution.

\subsection{Uptake and accumulation of total selenium in Zea mays}

The total selenium concentration in the plant is the sum of the selenium concentration in each tissue (Figure 3). Supplementation with selenite versus selenate resulted in significant differences in the distribution of selenium in whole plants and between tissues: in whole plants, selenium concentration was $68 \%$ higher in $\mathrm{Se}^{\mathrm{IV}}-\mathrm{T}$ versus $\mathrm{Se}^{\mathrm{VI}}-\mathrm{T}$ plants, with selenium 
241 concentrations of $210 \mu \mathrm{g} \cdot \mathrm{g}^{-1}(156 ; 225)$ and $125 \mu \mathrm{g} \cdot \mathrm{g}^{-1}(103 ; 126)$, respectively (Figure 3A).

242 Similarly but to a greater extent, selenium concentrations in roots were much higher (675\%)

243 in $\mathrm{Se}^{\mathrm{IV}}-\mathrm{T}$ versus $\mathrm{Se}^{\mathrm{VI}}-\mathrm{T}$ plants (Figure 3.B); and selenium concentrations in grains were 1.7

244 times greater, i.e. $73 \%$, in $\mathrm{Se}^{\mathrm{IV}}-\mathrm{T}$ versus $\mathrm{Se}^{\mathrm{VI}}-\mathrm{T}$ plants (Figure 3.E). Conversely, selenium

245 concentration in leaves was $73 \%$ lower in $\mathrm{Se}^{\mathrm{IV}}-\mathrm{T}$ compared to $\mathrm{Se}^{\mathrm{VI}}-\mathrm{T}$ plants (Figure 3.D).

246 Regardless of the inorganic form of selenium, the selenium concentrations in stems were

247 similar (Figure 3.C).

248 Based on the data for each tissue of Zea mays plants (Figure 3), we calculated the 249 selenium concentration in shoots (stems + leaves) and in tops (stems + leaves + grains). In 250 shoots and tops, selenium concentrations were $72 \mu \mathrm{g} \cdot \mathrm{g}^{-1}(66 ; 80)$ and $86 \mu \mathrm{g} \cdot \mathrm{g}^{-1}(86 ; 88)$ after 251 selenite treatment, and $151 \mu \mathrm{g} \cdot \mathrm{g}^{-1}(114 ; 154)$ and $126 \mu \mathrm{g} \cdot \mathrm{g}^{-1}(105 ; 130)$ after selenate 252 treatment, respectively.

253 Following root uptake, selenium can be redistributed to various degrees in the different plant 254 tissues. The translocation factor 'root-tops' (ratio of tops to roots concentrations) reflects the 255 capacity of selenium to be transferred to roots from aerial tissue. This ratio was lower with 256 selenite $(0.13(0.12 ; 0.13))$ than with selenate $(1.45(1.16 ; 1.49))$. The translocation factor 257 'shoot-grains' (ratio of grains to shoots concentrations) reflects the capacity of selenium to be 258 transferred to aerial vegetative tissue from grains. This ratio was higher with selenite $(2.03$ $259(1.66 ; 2.09))$ than with selenate $(0.51(0.49 ; 0.53))$.

260 Selenium amount (i.e. quantities in $\mu \mathrm{g}$ per plant or tissues) in tissues not only depends on 261 selenium concentrations but also on the biomass, which can vary considerably from one tissue 262 to another. Therefore, selenium amounts in each tissue provide important information about 263 selenium uptake by the plant. Selenium levels in whole plants were similar for selenite (4278 $264 \mu \mathrm{g}(4031 ; 5452))$ and selenate $(4813 \mu \mathrm{g}(3833 ; 5418))$. For selenate-treated plants, tops 265 accounted for more than $90 \%$ of the total selenium amount, with around $50 \%$ of total 
selenium found in the leaves (Figure 4). After selenite treatment, selenium amounts in the

267 three tissues differed dramatically: selenium amount in tops was low (about $40 \%$ of total plant

268 selenium) whereas around $60 \%$ of total plant selenium was found in the roots. Regardless of 269 the form of selenium supplied in the nutrient solution, selenium amount in grains represented $27015 \%$ of total plant selenium.

\subsection{Rate of selenium metabolization in Zea mays}

273 Concentrations of inorganic selenium species were determined after protease hydrolysis and

274 are presented in Table 1. The organic selenium fraction (i.e. pool of various organic selenium species) was estimated as the difference between total selenium extracted by protease hydrolysis and the sum of the inorganic species. This estimation is satisfactory for stems,

277 leaves and grains because the efficiency of enzyme hydrolyis is high, approximately $90 \%$. In 278 roots, where the efficiency of enzyme hydrolyis is only about $35 \%$, the fraction of non279 extractable selenium corresponds to chemically or physically sequestered organic selenium; 280 the percentage of inorganic selenium species is slightly over-estimated in this case.

281 After selenite treatment, neither selenate nor selenite was detected in any of the plant tissues.

282 Conversely, after selenate treatment, no trace of selenite was detected, but selenate was 283 identified in roots, stems and leaves, with a higher percentage in stems and leaves (54 $\pm 16 \%$ 284 and $39 \pm 9 \%$, respectively) than in roots $(20 \pm 5 \%)$. Finally, whatever the form of selenium 285 supplied, selenium was converted completely to organo-selenium compounds in grains. 


\section{DISCUSSION}

\subsection{Crop growth of Zea mays}

Leaf area is used to monitor aerial biomass production throughout plant development. Changes in leaf area usually follow three successive stages also observed in the three treatments of our experiment: 1) a growing stage where aerial biomass production is exponential, 2) a reproductive stage where foliar development becomes weak or null, and 3) finally a shoots (i.e. stems and leaves) senescence stage when grains are mature (Gitelson, Vina, Arkebauer, Rundquist, Keydan \& Leavitt, 2003).

Based on the dry weights of plants or tissues and the leaf areas, supplementation with inorganic selenium at high concentration $(12 \mu \mathrm{M})$ was harmful to Zea mays growth. In selenite-treated plants, the development of all tissues was affected, with a decrease in dry forage biomass as well as quantity (number) and quality (dry weight) of grains. A decrease in the leaf area of plants treated with selenite was observed only during the reproductive stage, i.e. between days 30 and 70 . The internodes that were affected by selenite treatment corresponded to those developed during the vegetative stages. Selenite toxicity has already been observed in white lupine and in sunflower, for example, with a biomass reduction of $20 \%$ and $40 \%$, respectively (with $12 \mu$ mol. $^{-1}{ }^{1}$ selenite) (Ximenez-Embun et al., 2004). These results contrast with data on Brassica rapa (Lyons et al., 2009), which showed that at very low selenium concentrations $\left(0.05 \mu \mathrm{mol}^{-1} \mathrm{l}^{-1}\right.$ selenite $)$ in hydroponic solution, plant biomass and dry weight of each grain were not affected, and moreover grain number increased by $43 \%$ for each plant. In selenate-treated plants, vegetative tissues of Zea mays were not affected, according to literature data on different varieties of crops (such as Zea mays and wheat) or other plants (such as pumpkin, buckwheat, dry beans) fertilized with different techniques (foliar application of selenate, selenate liquid or solid addition in soils, or fly-ash amendment) (Broadley et al., 2010; Cubadda et al., 2010; Mbagwu, 1983; Smrkolj et al., 2005; Stibilj et 
313 al., 2004). However, contrary to Mbagwu (1983) and Broadley et al. (2010), grain biomass

314 decreased in our study when plants were supplied with high selenate concentrations, although

315 there was only a small decrease in the number of grains. Selenate does not appear to influence

316 the quantity of grains but seems to inhibit their normal filling.

317 supplementation with selenate compared to selenite (De Souza et al., 1998; Terry et al., 2000; Ximenez-Embun et al., 2004; Zayed et al., 1998). However, some studies on rice, wheat or

333 compared directly to any previous data because our experiments were carried out on the 334 mature plant, unlike previous experiments conducted in young plants. Among those studies, Lyons et al. (2009) measured total selenium concentrations in roots, shoots and also seeds of Brassica rapa grown in hydroponic conditions, but the sodium selenite concentration in this

337 study was very low $\left(0.05 \mu\right.$ mol. $1^{-1}$ selenium $)$, i.e. 240 -fold lower than in our experiments. 
With selenite treatment, most of the selenium accumulated in roots. In Li et al. (2008),

339 Terry et al. (2000), De Souza et al. (1998) and Ximenez-Embun et al. (2004), the 'roots-tops'

340 translocation factor (0.5) was greater than that suggested by our result (0.13), but similar to 341 that of Lyons et al. (2009) (0.08). These two very similar results are the only data obtained

342 from experiments carried out up to the reproductive stage in a hydroponic system. The

343 developmental stage of the plant seems to influence the root storage capacity of selenium:

344 root uptake and accumulation appear to increase as the plants mature. Moreover, with selenite

345 treatment, organo-selenium compounds were produced to a greater extent than with selenate

346 treatment: in whole plants, no traces of inorganic selenium were detected. In several papers,

347 traces of selenite were detected in roots or shoots, but always less than $7 \%$, indicating that

348 selenium in plants is overwhelmingly organoselenium compounds (Ximenez-Embun et al.,

349 2004). With selenate treatment, most of the selenium taken up by Zea mays was translocated

350 and accumulated in the tops of plants, especially in the leaves; much less accumulated in roots

351 (Pickering, Prince, Salt \& Georges, 2000). In our study, the 'roots-tops' translocation factor

352 (1.45) was the same order of magnitude as published data (1.5-17) (De Souza et al., 1998; Li

353 et al., 2008; Terry et al., 2000). Selenate was metabolized less than selenite in whole plants.

354 This finding is coherent with the fact that reduction of selenate into selenite is the rate-

355 limiting step in selenate metabolism in plants (De Souza et al., 1998; Li et al., 2008; Terry et

356 al., 2000). Selenate absorbed by roots is metabolized to organic selenium compounds (that

357 represent only $20 \%$ of total selenium in roots) and/or is quickly translocated to the tops of

358 plants. The percentage of selenate in leaves (39\%) is less than in stems (54\%), which seems to

359 indicate that selenate is also metabolized in leaves. Mazej et al. (2008) and Li et al. (2008)

360 showed that on average, 60 to $100 \%$ of selenium in leaves and roots is selenate. In the results

361 presented by Ximenez et al. (2004) in India mustard, the selenate form represents $30 \%$ in

362 roots and $90 \%$ in shoots; moreover in sunflower, selenate in leaves (35\%) is similar to that in 
363

364

365

366

367

38345 to 500 ng.g ${ }^{-1}$ (Chilimba et al., 2011), while winter wheat grains (Broadley et al., 2010) can

384 accumulate up to $2.6 \mu \mathrm{g} \cdot \mathrm{g}^{-1}$. Only grains of wheat harvested in the Nawanshahr-Hosshiarpur 385 region of India had selenium concentrations similar to ours with 29 and $185 \mu \mathrm{g} . \mathrm{g}^{-1}$ (Cubadda 386 et al., 2010). These differences are probably due to the growing conditions, specifically the 387 soils or hydroponic solution. In our study, the hydroponic experiments allowed us to study the 
388 process of uptake in roots and translocation to shoots, which cannot be clearly identified in

389 soil due to its complex composition. Another explanation may be that phytic acid (a chelating

390 compound for trace elements) concentrations are higher in Zea mays grains than, for example,

391 in wheat grains (Egli et al., 2003), causing Zea mays to accumulate more selenium. .

392

4.3. Selenium enrichment of Zea mays to improve the quality of human and livestock

\section{food}

Unlike many studies, we were able to compare both selenate and selenite uptake in Zea mays

under the same experimental conditions: variations in the inorganic chemical form of supplied

selenium greatly influenced the ability of grains to accumulate selenium.

398 With selenate treatment, Zea mays grains with the lowest selenium concentrations

of selenate, Gissel-Nielsen (1986) found that selenium concentrations in barley grains were

equal to or slightly higher than in barley straw. On the other hand, with selenite treatment and

402 according to the literature (Cubadda et al., 2010; Mbagwu, 1983), selenium concentrations are

403 higher in grains than in shoots. In our study, grains contained twice as much selenium as

404 shoots, which is slightly higher than the levels reported by Cubadda et al. (2010) and Mbagwu

405 (1983) (around 1.15 times). Similarly, in field experiments and with different methods of

406 selenium application (granular fertilization and foliar application), selenium concentrations in

407 barley grains treated with selenite were on average 1.6 times higher than in straw (Gissel-

408 Nielsen, 1986). Thus, with selenite supplementation, grains appear to be a secondary tissue

409 for selenium storage after the roots.

410 These findings suggest that the use of selenite fertilizer could be attractive because (i) after

411 roots, selenium accumulates principally in grains; (ii) selenite is less mobile than selenate,

412 thereby enriching the soil in selenium at each fertilization, meaning that in the long term, 
413 plants grown on this soil will be enriched in selenium without the use of Se-fertilizers; and

414 (iii) the low mobility of selenite also limits selenium dispersion in the surrounding

415 environment. Moreover, another technique involving foliar application of selenite was found

416 to be more effective than granular fertilization for soybeans (Yang, Chen, Hu \& Pan, 2003).

417 Although not confirmed for rice (Hu, Chen, Xu, Zhang \& Pan, 2002), it would be interesting

418 to test this technology with Zea mays.

To improve dietary intake of selenium, the amount of selenium ingested is important but the quality and quantity of bioavailable selenium are also key factors. According to Thomson

422 (2004), the bioavailability of organic selenium is $90 \%$ compared with $50 \%$ for selenite or 423 selenate. Based on these data, we calculated selenium bioavailability for humans and animals in Zea mays in our experiment (Table 2).

425 Despite growth in highly variable conditions (species, concentrations and techniques of 426 selenium supplementation), all previous published results (Cubadda et al., 2010; Kapolna et 427 al., 2007; Smrkolj et al., 2007; Smrkolj et al., 2005), as well as the present data, show that 428 selenium in grains is, over-whelmingly, present as organo-selenium compounds. Furthermore, 429 Kalpona et al. (2007), Cubadda et al. (2010) and Smrkolj et al. (2005) showed that 430 selenomethionine represents around $80 \%$ of the total selenium in grains of sesame, wheat and 431 pumpkin, respectively. Consequently, the evaluation of bioavailable selenium for humans is 432 straightforward because bioavailable organic selenium accounts for $90 \%$ of total selenium in 433 grains. In our study, the bioavailable selenium per plant did not differ according to the form of 434 inorganic selenium supplied (Table 2). However, despite a decrease in grain biomass for the 435 selenite treatment at $12 \mu \mathrm{M}$, the bioavailable selenium concentration in grains was higher than 436 with selenate. In fields with granular selenium fertilization, selenium concentrations in wheat 437 or barley grains were higher with selenate than with selenite fertilizer (Gupta \& Winter, 1989; 
438 Singh, 1991). This difference is probably due to the fact that, in soil, selenite has lower

439 mobility and so is less bioavailable for plants compared to selenate. However, selenite can

440 enrich soil over the long term and avoid environmental pollution. Our results show that, at 441 equal ratios (i.e equal grain mass), and despite an observed decrease in grain biomass 442 production, the grains treated with selenite supply $73 \%$ more bioavailable selenium than those

443 treated with selenate (Table 2). Selenite is, therefore, the best treatment to enrich grains with

444 bioavailable selenium for animals and humans.

445 All aerial parts of plants (stems + leaves + grains $=$ tops) are used as forage for livestock. To 446 evaluate the bioavailable selenium for animals in our Zea mays plants, it was necessary to 447 take into account not only the selenium amount or concentration, but also the selenium 448 speciation. With selenite treatment, the biomass production of tops decreased, but $95 \%$ of the 449 selenium was organo-selenium whereas, with selenate, the biomass production of tops was 450 greater but the selenium was present as both organo-selenium compounds or selenate (less 451 bioavailable). So, based on selenium amount and speciation in tops, we conclude that plants 452 treated with selenate supply $148 \%$ more bioavailable selenium per plant compared to those 453 treated with selenite (Table 2). However, at equal ratios (i.e equal tops mass), tops treated 454 with selenite or selenate supply the same amount of bioavailable selenium (Table 2). Thus, 455 since selenate treatment does not affect shoot biomass, it is the best supplement to enrich 456 forage in bioavailable selenium for animals.

\section{5. CONCLUSIONS}

459 Our data suggest ways to improve agronomic biofortification of Zea mays with selenium. 460 The absorption, accumulation, distribution and metabolization of selenium in mature Zea 461 mays plants depend on the form of selenium supplied. Despite a decrease in grain biomass in 462 the presence of selenite or selenate in the nutrient solution, selenium is present mainly as 
463 organo-selenium compounds in grains. The choice of the form of selenium supplied strongly 464 influences the amount of bioavailable selenium in human and animal foodstuffs: to obtain the 465 highest selenium content for consumers (human or animal), selenate should be used for 466 animal feed and selenite for human food. Because health benefits associated with selenium as 467 well as its toxicity, the creation of dietary recommendations is a key challenge for human and 468 animal health. Nonetheless, data on selenium bioavailability in food are scarce in the 469 literature. Despite our specific experimental conditions (i.e. hydroponic), and although cereals 470 are considered non-accumulators, they do accumulate and metabolize selenium to organo471 selenium compounds: this study estimated, for the first time, selenium bioavailability in 472 edible parts for human and animals of an important cereal in the diet, Zea mays. 


\section{ABBREVIATIONS USED}

475 CRC-ICP-MS: Collision/reaction cell - Inductively coupled plasma mass spectrometry;

476 ICP-AES: Inductively coupled plasma atomic emission spectrometry;

477 GFAAS: graphite furnace atomic absorption spectrometry;

478 DW: Dry weight;

479 LOD: Limit of detection;

480 SD: Standard deviation;

481 FeEDDHA: Iron- Ethylenediaminedi-Q-hydroxyphenylacetic acid;

482 IRMM : Institute for Reference Materials and Mesurements 
Broadley, M. R., Alcock, J., Alford, J., Cartwright, P., Foot, I., Fairweather-Tait, S. J., Hart, D. J., Hurst, R., Knott, P., McGrath, S. P., Meacham, M. C., Norman, K., Mowat, H., Scott, P., Stroud, J., Tovey, M., Tucker, M., White, P. J., Young, S. D., \& Zhao, F. J. (2010). Selenium biofortification of high-yielding winter wheat (triticum aestivum L.) by liquid or granular Se fetilisation. Plant and Soil, 332, 5-18.

490 Chilimba, A., Young, S., Black, C., Rogerson, K., Ander, E., Watts, M., Lammel, J., \& 491 Broadley, M. (2011). Maize grain and soil surveys reveal suboptimal dietary selenium intake 492 is widespread in Malawi. Scientific Reports, 72.

493 Cubadda, F., Aureli, F., Ciardullo, S., D'Amato, M., Raggi, A., Acharya, R., Reddy, R. A. V., $\&$ Prakash, N. T. (2010). Changes in Selenium Speciation Associated with Increasing Tissue Concentrations of Selenium in Wheat Grain. Journal of Agricultural and Food Chemistry, 58, 2295-2301.

De Souza, M. P., Pilon-Smits, E. A. H., Mel Lytle, C., Hwang, S., Tai, J., Honma, T. S. U., Yeh, L., \& Terry, N. (1998). Rate-Limiting Steps in Selenium Assimilation and Volatilization by Indian Mustard. Plant Physiology, 117, 1487-1494.

Egli, I., Davidsson, L., Juillerat, M., Bearclay, D., \& Hurrell, R. (2003). Phytic acid degradation in complementary foods using phytase naturally occurring in whole grain cereals. Journal of Food Science, 68, 1855-1859.

Eurola, M. H., Ekholm, P. I., Ylinen, M. E., Koivistoinen, P. E., \& Varo, P. T. (1991). Selenium in Finnish foods after beginning the use of selenate supplemented fertilizers. Journal of the Science of Food and Agriculture, 56, 57-70.

Fakorede, M. A. D., Mulamba, N. N., \& Mock, J. J. (1977). A comparative study of methods used for estimating leaf area of mays (Zea mays L.) from non destructive measurements. Maydica, 22, 37-46.

Gissel-Nielsen, G. (1986). Comparison of selenium treatments of crops in the field. Biological Trace Element Research, 10, 209-213.

Gitelson, A. A., Vina, A., Arkebauer, T. J., Rundquist, D. C., Keydan, G., \& Leavitt, B. (2003). Remote estimation of leaf area index and green leaf biomass in maize canopies. Geophysical Research Letters, 30(5), 1248-1251.

Gupta, U. C., \& Winter, K. A. (1989). Effect of selenate vs. selenite forms of selenium increasing the selenium concentration in forages and cereals. Canadian Journal of Soil Science, 69, 885-888.

Hopper, J. L., \& Parker, D. R. (1999). Plant avaibility of selenite and selenate as influenced by the competing ions phosphate and sulfate. Plant and Soil, 210(2), 199-207.

$\mathrm{Hu}$, Q., Chen, L., Xu, J., Zhang, Y., \& Pan, G. (2002). Determination of selenium concentration in rice and the effect of foliar application of Se-enriched fertiliser or sodium selenite on the selenium content of rice. Journal of the Science of Food and Agriculture, 82, 869-872.

Hurrel, R. F. (2003). Influence of vegetable protein sources on trace element and mineral bioavailability. The journal of Nutrition, 133(9), 2973S-2977S.

Kapolna, E., Gergely, V., Dernovics, M., Illès, A., \& Fodor, P. (2007). Fate of selenium species in sesame seeds during simulated bakery process. Journal of Food Engineering, 79, 494-501.

Knowles, S. O., Grace, N. D., Wurms, K., \& Lee, J. (1999). Significance of Amount and Form of Dietary Selenium on Blood, Milk, and Casein Selenium Concentrations in Grazing Cows. Journal of Dairy Science, 82(2), 429-437.

531 Li, H. F., McGrath, S. P., \& Zhao, F. J. (2008). Selenium uptake, translocation and speciation 532 in wheat supplied with selenate or selenite. New Phytologist, 178(1), 92-102. 
Liu, K., \& Gu, Z. (2009). Selenium Accumulation in Different Brown Rice Cultivars and Its Distribution in Fractions. Journal of Agricultural and Food Chemistry, 57, 695-700. increases seed production in Brassica. Plant and Soil, 318, 73-80. in wheat grain, and the effect of postharvest processing on wheat selenium content. Biological Trace Element Research, 103, 155-168.

Mazej, D., Osvald, J., \& Stibilj, V. (2008). Selenium species in leaves of chicory, dandelion, lamb's lettuce and parsley. Food Chemistry, 107(1), 75-83.

Mbagwu, J. (1983). Selenium concentrations in crops grown on low-selenium soils as affected by fly-ash amendment. Plant and Soil, 74, 75-81.

Moore, K. L., Schroder, M., Lombi, E., Zhao, F. J., McGrath, S. P., Hawkesford, M. J., Shewry, P. R., \& Grovenor, C. R. M. (2010). NanoSIMS analysis of arsenic and selenium in cereal grain. New physiologist, 185, 434-445.

Nicholson, J., McQueen, R., \& Bush, R. (1991). Response of growing cattle to suplementation with organically bound or inorganic sources of selenium or yeast cultures. Canadian Journal of Animal Science, 71, 803-811.

550 Panel on Dietary Antioxidants and Related Compounds, Subcommittee on Upper Reference Levels of Nutrient, Subcommittee on Interpretation and Uses of DRIs, Standing Committee in the Evaluation of Dietary Reference Intakes of the Food and Nutrition Board, Institute of Medecine, \& the National Academies and Health Canada (2000). Dietary Reference Intake for Vitamin C, Vitamin E, Selenium and Carotenoids. Washington,DC: National Academies Press.

Pickering, I. J., Prince, R. C., Salt, D. E., \& Georges, G. N. (2000). Quantitative, chemically specific imaging of selenium transformation in plants. Proceedings of the National Academy of Sciences of the United States of America, 97(20), 10717-10722.

Podoll, K., Bernard, J., Ullrey, D., Debar, S., Ku, P., \& Magee, W. (1992). Dietary selenate versus selenite for cattle, sheep, and horses. Journal of Animal Science, 70, 1965-1970.

Rayman, M. P. (2008). Food-chain selenium and human health: emphasis on intake. British Journal of Nutrition, 100, 254-268.

Ruget, F., Bonhomme, R., \& Chartier, M. (1996). Estimation simple de la surface foliaire de plantes de maïs en croissance. Agronomie, 16, 553-562.

Singh, B. R. (1991). Selenium content of wheat as affectd by selenate and selenite contained in a Cl- or $\mathrm{SO}_{4}$-based MPK fertilizer. Fertilizer Research, 30, 1-7.

Smrkolj, P., Osvald, M., Osvald, J., \& Stibilj, V. (2007). Selenium uptake and species distribution in selenium-enroched bean (Phaseolus vulgaris L.) seeds obtained by two different cultivations. European Food Research and Technology, 225, 233-237.

Smrkolj, P., Stibilj, V., Kreft, I., \& Kapolina, E. (2005). Selenium species determination in selenium-enriched pumpkin (curcurbita pepo L.) seeds by HPLC-UV-HG-AFS. Analytical Sciences, 21, 1501-1504.

573 Stibilj, V., Kreft, I., \& Smrkolj, P. (2004). Enhanced selenium content in buckwheat 574 (Fagopyrum esculentum Moench) and pumpkin (Cucurbita pepo L.) seeds by foliar 575 fertilisation. European Food Research and Technology, 219, 142-144.

576 Terry, N., Zayed, A. M., De Souza, M. P., \& Tarun, A. S. (2000). Selenium in higher plants. Annual Review of Plant Physiology and Plant Molecular Biology, 51, 401-432. Thiry, C., Ruttens, A., De Temmerman, L., Schneider, Y., \& Pussemier, L. (2012). Current knowledge in species-related bioavailability of selenium in food. Food Chemistry, 130, 767784.

Thomson, C. (2004). Assessment of requirements for selenium and adequacy of selenium status: a review. European Journal of Clinical Nutrition, 58, 391-402. 
583 Ximenez-Embun, P., Alonso, I., Madrid-Albarran, Y., \& Camara, C. (2004). Establishment of

584 selenium uptake and species distribution in lupine, india mustard and sunflower plants.

585 Journal of Agricultural and Food Chemistry, 52, 832-838.

586 Yang, F., Chen, L., Hu, Q., \& Pan, G. (2003). Effect of the application of selenium on

587 selenium content of soybean and its products. Biological Trace Element Research, 93, 249-

588256.

589 Zayed, A., Lytle, C. M., \& Terry, N. (1998). Accumulation and volatilization of different 590 chemical species of selenium by plants. Planta, 206, 284-292.

591 Zhang, Y., Pan, G., Chen, J., \& Hu, Q. (2003). Uptake and transport of selenite and selenate 592 by soybean seedlings of two genotypes. Plant and Soil, 253, 437-443. 


\section{LIST OF FIGURES}

596 Figure 1. Change in leaf area $\left(\mathrm{cm}^{2}\right)(\mathrm{A})$ and internode length $(\mathrm{cm})(\mathrm{B})$ of Zea mays plants 597 with the three different treatments.

598 Figure 2. Dry biomass production (\%) in Zea mays plants (A) or in grains (B) and number of

599 grains per plant (C) with the three different treatments: C-T (dots), Se ${ }^{\mathrm{VI}}-\mathrm{T}$ (light gray) and $600 \quad \mathrm{Se}^{\mathrm{IV}}-\mathrm{T}$ (dark gray).

601 Figure 3. Selenium concentrations $(\mu \mathrm{g} / \mathrm{g}$ DW) in whole Zea mays plants (A) or in different 602 tissues of Zea mays plants with the two different treatments (B. roots, C. stems, D. leaves and 603 E. grains): $\mathrm{Se}^{\mathrm{VI}}-\mathrm{T}$ (light gray) and $\mathrm{Se}^{\mathrm{IV}}-\mathrm{T}$ (dark gray).

604 Figure 4. Schematic representation of a Zea mays plant showing the selenium amount (\%) in 605 roots, stems, leaves, and grains treated with $\mathrm{Se}^{\mathrm{VI}}-\mathrm{T}$ (left) or $\mathrm{Se}^{\mathrm{IV}}-\mathrm{T}$ (right).

606 Table 1. Selenium species in Zea mays after enzyme hydrolysis.

607 Table 2. Estimated concentration $(\mu \mathrm{g} / \mathrm{g})$ and amount $(\mu \mathrm{g} / \mathrm{plant})$ of selenium bioavailable for 608 animals (tops of plant) or humans (grains of plant) with the two selenium treatments: $\mathrm{Se}^{\mathrm{VI}}-\mathrm{T}$ 609 and $\mathrm{Se}^{\mathrm{IV}}-\mathrm{T}$.

610 
611 Figure 1. Change in leaf area $\left(\mathrm{cm}^{2}\right)(\mathrm{A})$ and internode length $(\mathrm{cm})(\mathrm{B})$ of Zea mays plants 612 with the three different treatments.

613 A

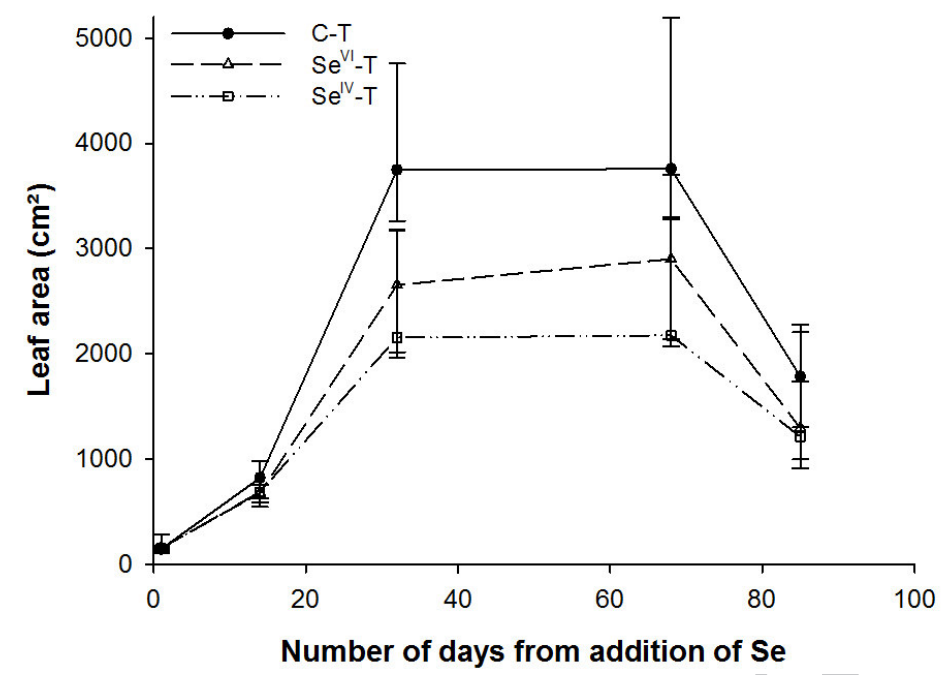

614

615 B

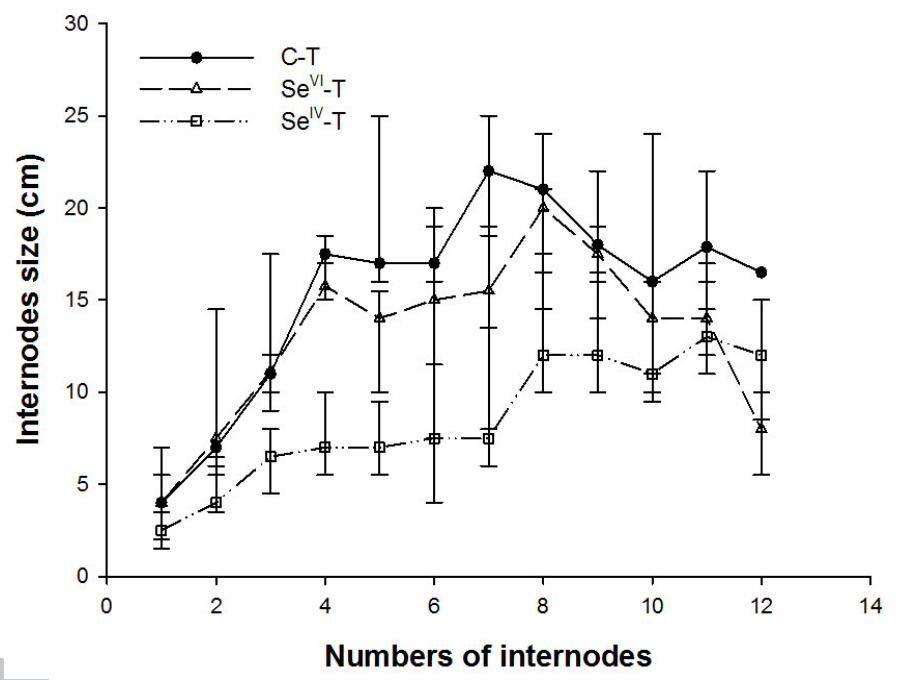

616

617

618 Values are medians (lower: $10^{\text {th }}$ percentile; upper: $90^{\text {th }}$ percentile) 
619 Figure 2. (A) Dry biomass production (\%) of Zea mays plants (A) or of grains (B) and 620 number of grains per plant (C) with the three different treatments: C-T (dots), Se ${ }^{\mathrm{VI}}-\mathrm{T}$ (light 621 gray) and $\mathrm{Se}^{\mathrm{IV}}-\mathrm{T}$ (dark gray).

622

623
A

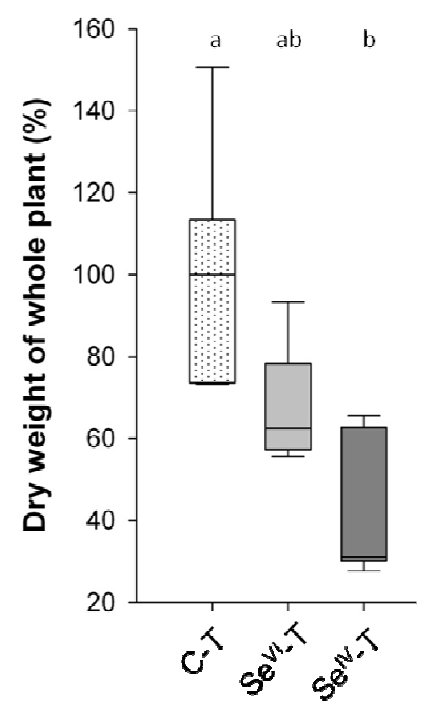

B

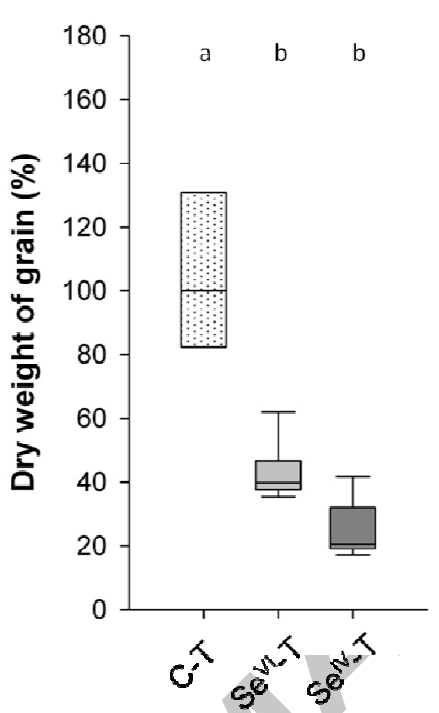

C

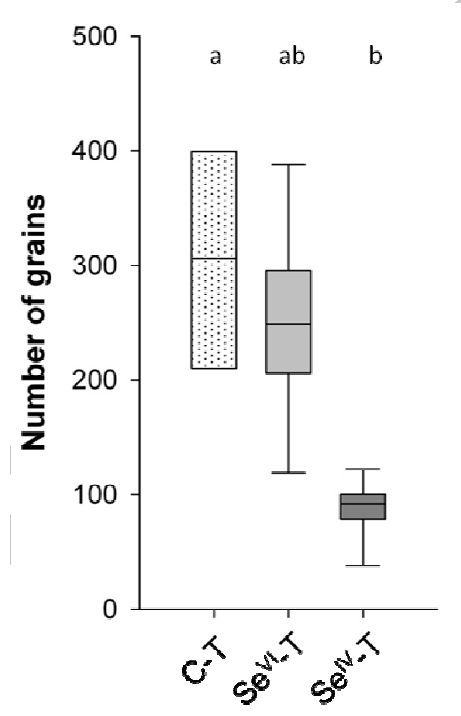

a, b: results of Kruskal-Wallis test 
625 Figure 3. Selenium concentrations $(\mu \mathrm{g} / \mathrm{g}$ DW) in whole Zea mays plants (A) or in different 626 tissues of Zea mays plants with the two different treatments (B. roots, C. stems, D. leaves and 627 E. grains): $\mathrm{Se}^{\mathrm{VI}}-\mathrm{T}$ (light gray) and $\mathrm{Se}^{\mathrm{IV}}-\mathrm{T}$ (dark gray).

628

629
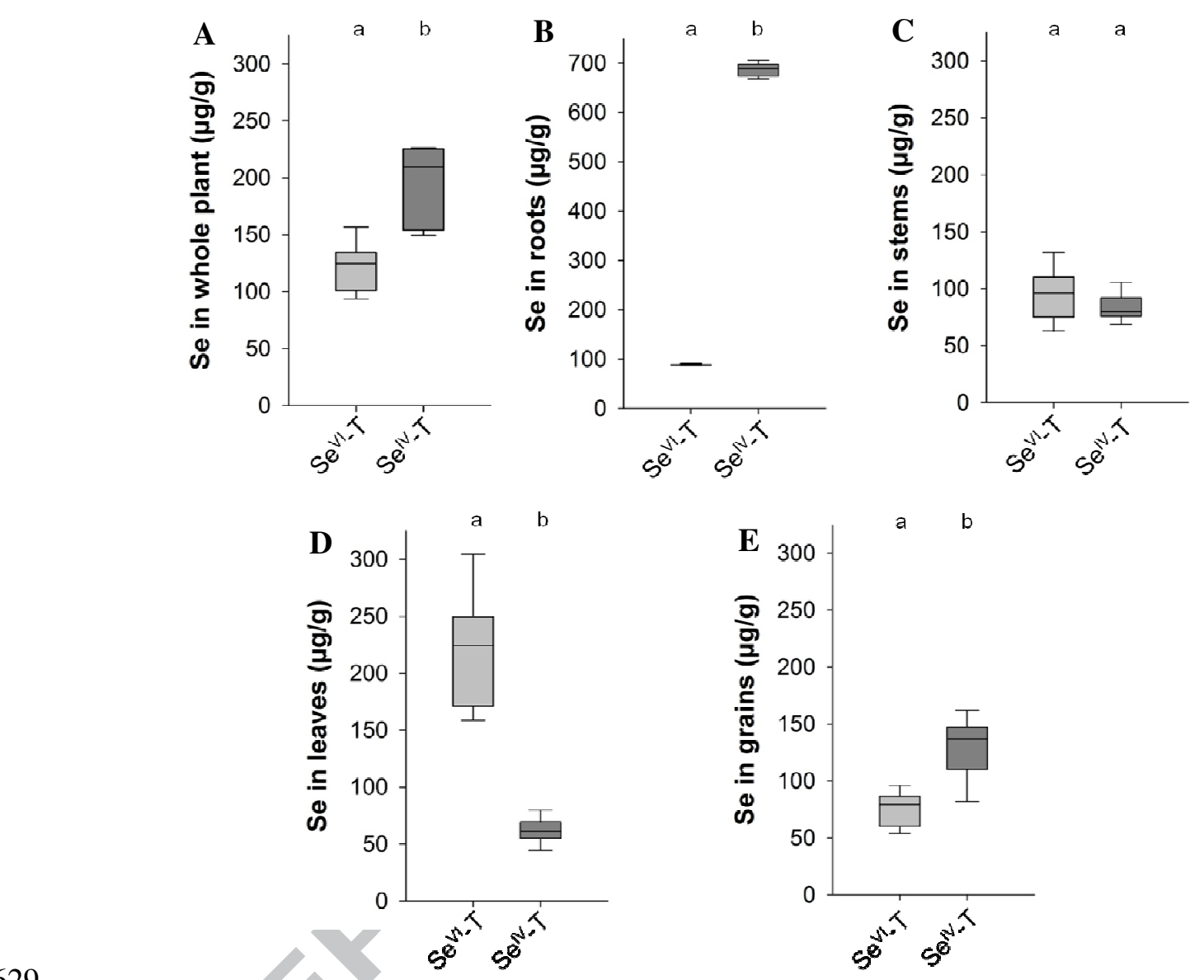

630 $a, b$ : results of Mann and Whitney test

631

632

633

634

635

636 
637 Figure 4. Schematic representation of a Zea mays plant showing the selenium amount (\%) in 638 roots, stems, leaves, and grains treated with $\mathrm{Se}^{\mathrm{VI}}-\mathrm{T}$ (left) or $\mathrm{Se}^{\mathrm{IV}}-\mathrm{T}$ (right).

639

640

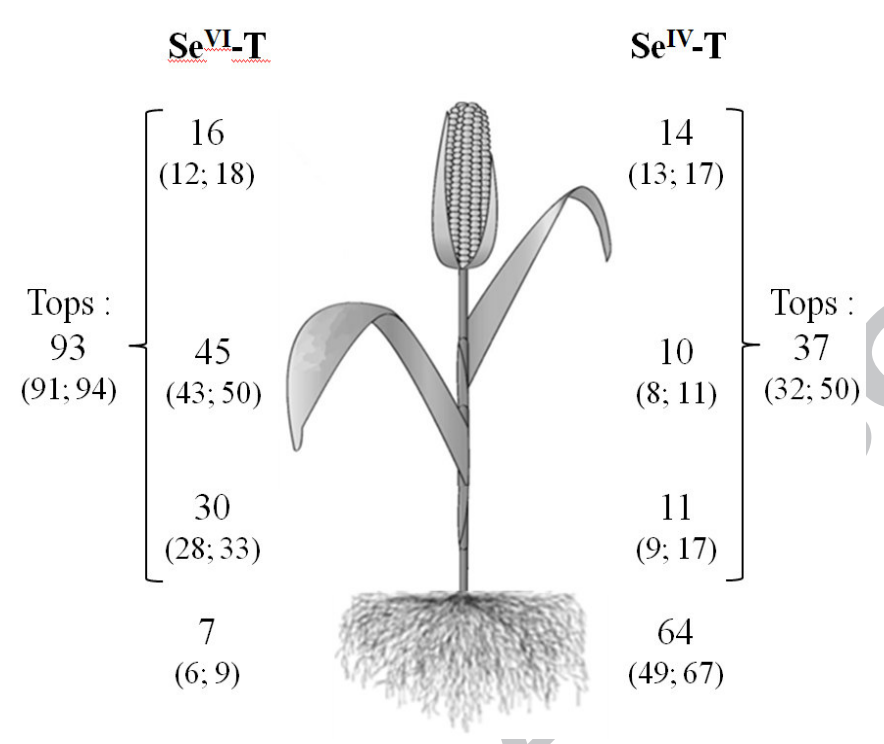

$641 \quad$ Values are medians $(Q 1 ; Q 3)$

642 
643 Table 1. Selenium species in Zea mays after enzyme hydrolysis.

644

645

\begin{tabular}{lc|ccc|ccc} 
& & \multicolumn{3}{|c|}{ Se $^{\mathrm{VI}}-\mathbf{T}$} & \multicolumn{3}{c}{ Se $^{\mathrm{IV}}-\mathbf{T}$} \\
\hline & $\begin{array}{c}\text { Efficiency of } \\
\text { enzyme hydrolyis } \\
(\%)\end{array}$ & \multicolumn{3}{|c|}{ Se fraction $(\%)^{\mathrm{a}}$} & \multicolumn{3}{c}{ Se fraction $(\%)^{\mathrm{a}}$} \\
\hline Roots & $36 \pm 8$ & $20 \pm 5$ & ND & 80 & ND & ND & $\geq 95$ \\
Stems & $89 \pm 13$ & $54 \pm 16$ & ND & 46 & ND & ND & $\geq 95$ \\
Leaves & $93 \pm 6$ & $39 \pm 9$ & ND & 61 & ND & ND & $\geq 95$ \\
Grains & $104 \pm 7$ & ND & ND & $\geq 95$ & ND & ND & $\geq 95$ \\
\hline
\end{tabular}

646

$647{ }^{a} \%$ of Se species after protease hydrolysis

$648{ }^{b}$ difference between total Se extracted by protease hydrolysis and sum of inorganic species

649 Values are means $\pm S D$ 
650 Table 2. Estimated concentration $(\mu \mathrm{g} / \mathrm{g})$ and amount $(\mu \mathrm{g} / \mathrm{plant})$ of selenium bioavailable for

651 animals (tops of plant) or humans (grains of plant) with the two selenium treatments: $\mathrm{Se}^{\mathrm{VI}}-\mathrm{T}$

652 and $\mathrm{Se}^{\mathrm{IV}}-\mathrm{T}$.

653

654

655

656

657

658

659

Values are medians $(Q 1 ; Q 3)$

$660 \quad a, b$ : results of Mann-Whitney test

661 